\title{
O CONFLITO ENTRE O ISLÃ E O OCIDENTE: DA ASCENSÃO DOS ÁRABES AO OCASO OTOMANO
}

André Leme Lopes*

Resumo: Este artigo pontua alguns momentos das relações bélicas entre os Estados de religião islâmica e a Europa cristã. A análise se concentrará na ascensão do império dos califas, no século VI; na instituição da ‘civilização’ islâmica pelo califa Abd Al-Malik; na época das cruzadas e na expansão e posterior derrota do império turco dos descendentes de Osman.

Palavras-chave: História da guerra; Islã; Cristandade; califado árabe; cruzadas; assassinos; império otomano.

Minha intenção neste espaço é pontuar alguns momentos da tumultuada relação entre a civilização islâmica e a civilização ocidental, desde a aurora da primeira. ${ }^{1}$ Não é meu objetivo realizar um levantamento exaustivo de todas as situações de enfrentamento militar ou diplomático e muito menos discutir as relações comerciais entre esses dois 'mundos', mas apenas apresentar uma tentativa de contextualizar historicamente algumas passagens importantes da relação entre a religião muçulmana e os cristãos europeus. Nesse sentido, evitei ao máximo as referências bibliográficas acrescentando, apenas, algumas sugestões de leitura adicional ao final do artigo.

Minha análise irá se concentrar em três pontos: 1) a ascensão do império dos califas, quando os nômades da Arábia, recém-unificados pela nova fé, retalharam o Império Romano do Oriente; 2) a época das Cruzadas, quando os cristãos europeus recuperaram a península ibérica e controlaram trecho significativo do Levante por mais de um século; 3) o Império Otomano, que, após séculos de expansão avassaladora pela Europa Oriental, foram, de maneira não menos surpreendente, completamente derrotados pelas armas cristãs.

\footnotetext{
* Mestre em História Social e das Idéias - UnB; doutorando em História das Idéias - UnB; Professor da Unip.

${ }^{1}$ Para uma discussão mais aprofundada da aplicação do termo 'civilização' às entidades 'Islã' e 'Ocidente', ver, nesta mesma edição, o artigo de Rodrigo Falcão, "Oriente e Ocidente: a terra dos vivos, a terra dos mortos".
} 


\section{O profeta e os califas}

Segundo uma tradição medieval, no início do século VII os imperadores de Constantinopla e Ctesifonte teriam recebido uma carta enviada por Mohamed, um desconhecido habitante de uma cidade desconhecida: Meca, na Arábia. Nessa mensagem, Mohamed declarava que, pela voz do arcanjo Gabriel, Deus lhe havia feito uma revelação; uma revelação que completava e corrigia as anteriores, feitas a Moisés e Cristo e deturpadas por seus seguidores. Mohamed instava os imperadores a abraçarem a nova fé e se submeterem ao Islām, uma palavra árabe, derivada da mesma raiz semítica que o hebraico shālom, 'paz', que significava 'entrar em uma condição de paz e segurança através da lealdade e da submissão a Deus'.

Menos de meio século depois, os exércitos muçulmanos haviam finalmente encerrado a longa guerra entre Roma e a Pérsia, conquistando completamente o segundo império e as terras mais ricas e férteis do primeiro. No início do século VIII, berberes convertidos ao Islã desembarcaram na Espanha e, na metade do mesmo século, os muçulmanos derrotariam um exército chinês. O império criado por essa vitoriosa expansão militar duraria seis séculos.

Apesar da evidente superioridade, a principal vantagem dos árabes não era de caráter militar. Ao contrário, a qualidade de suas armas era inferior e os séculos de rixas tribais no deserto não lhes deram nenhuma experiência de guerra intensiva. ${ }^{2} \mathrm{O}$ que lhes permitiu conquistar persas e bizantinos foi a unidade proporcionada pela religião: o mundo era dividido em duas regiões, a ‘casa da submissão' (dār al-Islām) e a 'casa da guerra' (dār $a l$-harb), e era objetivo dos fiéis unir o mundo em uma única 'umma ('comunidade'). ${ }^{3}$ Com

\footnotetext{
2 A principal montaria dos árabes era o camelo (o famoso cavalo árabe já existia, mas seu número era pequeno), animal excepcionalmente resistente. Como meio de transporte, possibilitava uma vantagem estratégica, permitindo a travessia de áreas desérticas que os exércitos civilizados julgavam impenetráveis. Como arma de combate, no entanto, era um animal lento e desajeitado.

3 “Tu que crês, combate os infiéis que estão perto de ti” (Alcorão, 9, 125). Não se deve, no entanto, associar a expansão político-militar árabe à expansão da fé islâmica. Embora, sem sombra de dúvida, diversos povos só tenham se convertido ao Islã após sua conquista pelos árabes, o objetivo destes não era a conversão dos primeiros. O Alcorão é bastante claro a esse respeito: "não há compulsão pela religião" $(2,256)$, ou seja, nenhuma conversão realizada pela força é válida. A conversão tem que ser sincera e, portanto, partir da vontade do infiel de se submeter a Deus. Os infiéis que se submeterem à autoridade dos califas estarão protegidos pelo seu poder e aqueles que não ameaçarem o Islã deverão ser deixados em paz.

Talvez o maior fator que induz à associação entre conquista e conversão é a incompreensão da noção de jihād, palavra árabe habitualmente traduzida como 'guerra santa'. Na verdade, o termo jihād é parte da expressão
} 
isso, o Islã dissolveu os dois princípios pelos quais se costumava guerrear, território e parentesco: todos os homens são irmãos e todo o mundo deve estar submetido a Deus.

Outro fator que possibilitou a expansão dos árabes foi a atitude dos próprios povos conquistados. Iranianos e berberes se converteram rapidamente ao Islã e, juntamente com os árabes ou por sua própria conta, dominaram e converteram à fé diversos povos na África e na Ásia. Os persas tornaram-se a própria base burocrática do império árabe, e, ainda hoje, a cultura iraniana traz muitos elementos persas e árabes. Já os cristãos do Egito e da Síria, sempre às voltas com as tentativas de Constantinopla e Roma de impor a ortodoxia cristã, simplesmente trocaram um domínio estrangeiro por outro - com a imensa vantagem de que os muçulmanos não interferiam na maneira como eles adoravam a Cristo. $\mathrm{O}$ mesmo valia para os judeus: o Islã lhes era muito mais tolerante do que a ortodoxia cristã ou o zoroastrismo persa.

De qualquer modo, a grande obra da religião islâmica não foi a submissão políticomilitar dos últimos impérios do mundo antigo. Essa foi a conversão cultural e religiosa das áreas conquistadas. Em todas as regiões conquistadas pelos árabes, com a exceção da Europa, do Irã e da Ásia central, o árabe é, hoje, mais de sete séculos após a derrubada do califado, a língua popular, a língua de cultura, do comércio e do governo. Como língua religiosa, o árabe se espalhou ainda mais, chegando a regiões da Ásia e da África que nunca conheceram o domínio árabe.

\section{A ‘civilização’ muçulmana}

É interessante observar que, no início, o mundo cristão não via o islamismo como uma nova religião ou como uma 'civilização' diferente. Com frequiência os textos bizantinos tratam a nova religião como apenas mais uma heresia cristã. A construção da

jihād fì sabīl Allāh, que significa 'lutando pela causa de Deus'. Trata-se, no entanto, da luta que se dá na alma de cada indivíduo, a luta contra o mal e contra as tentações. Apenas o 'pequeno jihād', a defesa do Islã contra agressões externas, pode resultar em luta física (embora também possa ser levado a cabo na forma de discursos ou escritos). Mas, mesmo quando a jihād toma a forma de guerra, existem diversas regras prescritas pelo Profeta que visam à correta conduta dos combatentes e à defesa dos inocentes. A falha em observar esses mandamentos é uma ofensa pela qual o fiel deverá responder no dia do Juízo Final. 
hoje tão famosa 'civilização islâmica' foi obra dos califas da dinastia omíada, que tomaram o poder após o assassinato, em 661, do quarto califa, Ali, genro do Profeta. ${ }^{4}$

Foi Abd al-Malik, o quinto dos califas omíadas, quem iniciou o processo chamado pelos historiadores árabes de 'organização e ajustamento'. Até então, os califas árabes, um pouco como os conquistadores bárbaros do império romano, eram habitantes de um mundo alienígena cuja vida continuava sob a proteção de seu poder. Abd al-Malik começou por substituir as estruturas administrativas persa e bizantina, usadas pelos califas anteriores, por uma burocracia imperial na qual o árabe substituiu as línguas imperiais como língua administrativa e financeira. Na mesma época, introduziu uma nova moeda de ouro, o dinar - nome derivado do romano denarius. Além do desafio da cunhagem de moedas de ouro, ${ }^{5}$ Abd al-Malik mandou inscrever nessas moedas versículos do Alcorão que declaravam o Islã como uma nova religião, independente das anteriores:

Foi Ele quem enviou seu mensageiro com a Sua orientação e a religião verdadeira para que a faça prevalecer sobre todas as outras (9: 33).

Tão importante quanto a cunhagem das novas moedas, estava a construção de edifícios públicos. O maior e mais importante foi o Domo da Rocha, erigido no Monte do Templo, em Jerusalém, no local em que, segundo a tradição rabínica, Deus exigiu de Abraão o sacrifício de seu filho Isaac. Mais importante do que o local, por si só carregado de simbolismo, eram os versículos do Alcorão que decoravam o interior. Entre eles, o tex to completo da sura 112:

\footnotetext{
${ }^{4}$ Quando Mohamed morreu, nenhuma providência havia sido tomada para organizar sua sucessão. Por consenso do círculo de seguidores mais próximos do Profeta, Abu Bakr, um dos primeiros conversos ao Islã, foi escolhido como khalīfa, isto é, 'sucessor' do Profeta ou, por uma feliz ambigüidade do árabe, 'representante' de Deus. Desde muito cedo, no entanto, houve uma disputa entre aqueles que desejavam que a sucessão se desse por eleição e os partidários da transmissão do poder pela família do Profeta. A disputa explodiu em guerra civil desde a sucessão de Uthman, o terceiro califa, e os fiéis se dividiram em dois grupos: os xiitas, isto é, membros do 'partido' (Shī'a) de Ali, e os sunitas, seguidores da 'tradição' (sunna) do Profeta. Não se pode deixar de observar que, durante a guerra civil, entre 674 e 678, os muçulmanos sitiaram, pela primeira vez, Constantinopla, capital do Império Romano, uma das maiores provas de sua extraordinária força militar. A guerra só terminou em 680, quando, na batalha conhecida pelo nome de 'massacre de Karbala', o exército omíada esmagou os xiitas, tragédia completada pelo assassinato do filho de Ali, al-Husayn, e de todos os homens de sua família (apenas uma criança doente, filha de Husayn, escapou) e pelo estupro e tortura das mulheres da família do Profeta.

${ }^{5}$ Desde sua criação na antiga Mesopotâmia, as moedas sempre foram símbolos de poder e autoridade. A cunhagem de moedas de ouro era exclusividade dos imperadores romanos e os califas anteriores mantiveram as moedas bizantinas e persas em circulação, cunhando apenas moedas de prata - e, mesmo estas, em modelos bizantinos.
} 
Ele é o Deus único. Deus, o eterno refúgio. Nem gerou nem foi gerado. Ninguém é igual a ele.

Outro trecho, retirado da sura 3, adverte explicitamente contra os erros das revelações anteriores:

Ó, adeptos do livro! Não cometei excessos em vossa religião e nada dizei de Deus não seja a verdade. Jesus Cristo, o filho de Maria, foi na verdade um apóstolo de Deus... portanto acreditai em Deus e em seus apóstolos e não dizeis "três". Desisti e será melhor para vós, pois Deus é, na verdade, um único Deus, glorificado demais para ter um filho...

O significado de tudo isso era simultaneamente político e religioso. Só a religião poderia justificar o império. Só o império poderia sustentar a religião. O Islã não era um sucessor do cristianismo; era uma nova e universal revelação. Tornava-se claro, assim, que um novo Estado universal e uma nova religião mundial haviam surgido. As inscrições no interior do Domo da Rocha atestavam a ligação do islã com as religiões precursoras, o judaísmo e o cristianismo, mas, ao mesmo tempo, deixava claro que a nova revelação viera para corrigir-lhes os erros e substituí-las.

\section{A reação da Cristandade}

Se para os muçulmanos o mundo cristão era o Império Romano do Oriente, ${ }^{6}$ a cristandade não-bizantina conheceu os muçulmanos principalmente através da invasão da península ibérica. A dinastia carolíngia, principalmente, se valeu de seu papel crucial na vitória de Poitiers (732) para, com o apoio do papa, ascender como o principal poder político da Europa ocidental. ${ }^{7}$

O fenômeno que dominou a história das relações entre a Europa e o mundo muçulmano, durante os séculos IX e X, foi a pirataria sarracena no Mediterrâneo ocidental.

\footnotetext{
${ }^{6}$ É interessante observarmos que o império amplamente conhecido na historiografia como 'bizantino' nunca é denominado assim por seus contemporâneos. Os próprios bizantinos se denominavam 'romanos' e os demais Estados os conheciam como Império Romano ou simplesmente România. O termo árabe 'Rum', que denominava o império seljúcida dos séculos XI e XII, também se refere a sua localização nos territórios conquistados ao Império Romano do Oriente.

${ }^{7} \mathrm{Se}$ os contemporâneos já percebiam tais enfrentamentos como um 'conflito de civilizações' é matéria discutível. A principal evidência para tal tese é a Crônica moçárabe, de 754, que designa os francos que lutaram em Poitiers pelo termo 'europenses'. Para os muçulmanos, no entanto, tais eventos ocorriam em regiões periféricas de seus domínios e não eram vistos como grandes acontecimentos.
} 
A partir do século XI, no entanto, a direção das iniciativas se inverteu e foi o Ocidente que atacou o mundo muçulmano. Iniciava-se a época da Reconquista e das Cruzadas.

A iniciativa cristã foi de encontro a um mundo muçulmano bastante diferente daquele de Abd al-Malik. Ainda no século VIII, os abássidas, descendentes de um tio do profeta, al-Abbas, derrubaram o califado omíada e transferiram a capital do império para a recém-fundada Madinat al-Salam, a Cidade da Paz, atual Bagdá. Embora a própria composição étnica do império houvesse mudado - os árabes, dominantes sob os omíadas, dividiam seu poder com os aliados iranianos dos abássidas -, durante várias décadas os califas abássidas reinaram sobre um império florescente. ${ }^{8}$ Mas já nos primeiros anos do século X, a autoridade dos califas praticamente não existia. Os verdadeiros governantes do califado eram os líderes militares locais.

Além disso, um outro poder político aspirava à autoridade universal no mundo muçulmano. Partindo do Iêmen, exércitos xiitas ocuparam o norte da África e desafiaram o império abássida em sua supremacia política e religiosa, declarando-se califas. O nome utilizado por esses califas foi 'fatímida', enfatizando sua descendência de Fátima, filha do Profeta e esposa de Ali. Em 969, al-Muizz, quarto califa fatímida, conquistou o Egito e erigiu a grande cidade do Cairo para ser sua capital.

Mais ou menos nessa mesma época, um grupo de turcos oghuzes, expulsos de suas terras por turcos rivais, emigrou para o território islâmico. A mais importante dessas migrações foi liderada pela família dos seljúcidas, que se instalaram em Bucara, converteram-se ao Islã, e serviram a diversos governantes e dinastias. ${ }^{9}$ Já no início do século XI, no entanto, possuíam a autoridade de fato no Irã oriental: já em 1055, Tughrul, neto de Seljuk, ocupou Bagdá e, pouco depois, tomou a Síria e a Palestina dos governadores locais. A partir daí, como o império abássida antes dele, o império seljúcida se fragmentou sob a liderança de diversos guerreiros locais. Sua expansão, no entanto,

\footnotetext{
${ }^{8} \mathrm{O}$ auge do califado abássida se deu sob o governo de Harun al-Rachid (786-809), famoso no Ocidente pelas histórias de As mil e uma noites.

${ }^{9}$ A conversão dos turcos ao Islã é um dos fatos mais notáveis da história da humanidade. A sinceridade com que eles abraçaram a nova fé foi total e todos os resquícios do passado turco pré-islâmico - religiões, literaturas, Estados - foram completamente esquecidos. No entusiasmo e sinceridade da lealdade ao Islã, nenhum povo os igualou.
} 
continuou e exércitos seljúcidas ocuparam a maior parte da península anatólica, onde seriam os primeiros muçulmanos atacados pelos exércitos cristãos nas Cruzadas.

Divididos entre principados turcos seljúcidas, nominalmente sujeitos à autoridade do califa de Bagdá, e um decadente califado fatímida no Cairo, os muçulmanos demoraram quase cem anos para reagir efetivamente ao ataque cristão. Com efeito, se os cruzados ocupam Antioquia e Edessa em 1098 e Jerusalém em 1099, é apenas em 1187 que Salah alDin (conhecido no Ocidente como Saladino) conseguirá pela primeira vez derrotar significativamente os cruzados cristãos na batalha de Hattin, retomando Jerusalém e expulsando os cruzados para a costa do Levante. Ainda se passariam outros cem anos antes de São João de Acre, a última fortaleza cruzada no Levante, ser tomada pelos sultões mamelucos do Egito.

Militarmente, as Cruzadas foram o primeiro momento no qual houve, se não superioridade dos exércitos cristãos, ao menos igualdade entre este e o Islã. Os exércitos muçulmanos, especialmente no Egito e na Síria, dependiam muito da cavalaria ligeira árabe e berbere, que, lutando corpo-a-corpo, com lança e espada, não podia competir com os pesados e encouraçados cavaleiros cruzados. Estes, por sua vez, dependiam da força esmagadora da carga de cavalaria, que podia, em um único ataque, desbaratar completamente o exército inimigo. A questão central, senão única, da tática de guerra européia era escolher o momento certo de soltar a cavalaria e atingir, em uma carga devastadora, o corpo principal do inimigo. O problema foi que, na Europa, era uma questão de honra para os cavaleiros enfrentarem tal carga de frente. Nas cruzadas, os europeus se defrontaram com um inimigo estranho, que manobrava e se esquivava do ataque dos cavaleiros. Com o passar do tempo, os cruzados tentaram se adaptar ao desafio, incorporando soldados de infantaria e escolhendo locais em que os flancos das formações de cavaleiros ficassem naturalmente protegidos. A balança só pendeu definitivamente contra os cruzados quando as disputas internas ao Islã diminuíram de intensidade e, inferiorizados numericamente, sua carga de cavalaria deixou de ter a força definidora que tinha antes.

O momento mesmo da vitória muçulmana foi seguido por uma das mais dramáticas derrotas da história do Islã. Na metade do século XIII, os exércitos mongóis avançaram 
sobre a planície iraniana. De início, a aproximação dos exércitos comandados por Hulegu, neto de Gêngis Khan, não causou alarme, pois era dirigida contra a seita radical dos Assassinos - a destruição da fortaleza de Alamut foi saudada em Bagdá como uma grande vitória. ${ }^{10}$ Em 1257, no entanto, Hulegu entrou na Pérsia e, em janeiro de 1258, capturou Bagdá e estrangulou o califa al-Mutasim. O império abássida chegara ao fim.

\section{O Islã após a queda do califado}

Nos séculos que se seguiram às conquistas mongóis e à destruição do califado, três centros de poder emergiram no Oriente Médio muçulmano: o Irã, a Turquia e o Egito. O primeiro, governado por uma linhagem de khans mongóis, converteu-se ao islamismo, embora tenha conservado importantes elementos da tradição mongol; o segundo, governado por príncipes turcos, muçulmanos, foi, por um tempo, vassalo dos mongóis; o terceiro, sob o governo dos sultões mamelucos, resistiu aos exércitos mongóis e reconquistou e manteve com sucesso a Síria.

Esse período presenciou uma série de iniciativas diplomáticas interessantes entre os mongóis e a Europa cristã, com o objetivo de planejar uma guerra em duas frentes contra o inimigo comum islâmico. Tais tentativas nunca obtiveram resultado e, em breve, o Irã mongol enfrentaria seus próprios problemas no oriente com a invasão de Timur Lang, conhecido na Europa como Tamerlão.

O Egito foi, no primeiro instante após a destituição dos califas, o principal centro do mundo árabe. A invasão de Timur, seguida por pestes, gafanhotos e ataques de beduínos, no entanto, foi um golpe do qual o sultanato mameluco nunca conseguiu se recuperar.

Da mesma maneira, o império seljúcida foi completamente destruído pela invasão mongol e os turcos sobreviveram na Anatólia sob a forma de pequenos principados sujeitos

\footnotetext{
${ }^{10}$ Os Nizārī despertam ainda hoje muita curiosidade, pois foram considerados por alguns historiadores como o primeiro grupo terrorista da história. Com efeito, sua tática era simples: o assassinato de líderes inimigos. Foram tão eficazes nisso que emprestaram seu nome à atividade: a fidelidade e o fanatismo dos membros da seita era tão grande que os muçulmanos da Síria acreditavam que eles agiam sob a influência do haxixe (daí o nome hashīshīn, 'consumidores de haxixe', que levou ao termo ocidental 'assassino'). Os Assassinos, no entanto, nada tinham a ver com a Cruzada e estiveram mais freqüentemente aliados aos cristãos do que contra esses. Eram radicais xiitas e seus principais alvos eram muçulmanos sunitas ou xiitas considerados hereges ou traidores.
} 
à autoridade do Irã mongol. Um desses principados se transformou em um vasto império. Localizado no extremo ocidente da Anatólia, esse principado estava longe dos mongóis e próximo das riquezas da decadente Constantinopla. Com efeito, Osmã e seus sucessores travaram uma guerra constante e sempre vitoriosa contra os bizantinos: em 1326 ocuparam Bursa, que se tornou a capital de seu império por mais de cem anos; em 1354, cruzaram o Dardanelos e ocuparam Galípoli e Adrianopla, na Trácia; por fim, uma série de campanhas vitoriosas contra os sérvios e os búlgaros submeteram a maior parte da península balcânica ao domínio otomano. Todas essas conquistas européias foram acompanhadas de expansões territoriais, às vezes pacíficas, na Anatólia e, quando o quarto sultão otomano, Bayezid I, solicitou ao califa do Cairo o título de 'Sultão de Rum', era a velha monarquia islâmica da Anatólia que ele pretendia restaurar.

Bayezid, no entanto, foi derrotado em Ancara por Timur em 1402 e suicidou-se no cativeiro. Por vinte anos seu filho Mehmed I concentrou-se em restaurar e consolidar o Estado otomano, derrotando a oposição interna. Assim, mesmo derrotado por Tamerlão, o império otomano pôde sobreviver como força significativa, enquanto o Egito mameluco afundava em crises. Murad II (1421-1451) completou a obra de seu pai no âmbito interno e retomou a expansão, tanto na Europa quanto na Anatólia. Quando Murad morreu, o principado otomano era um grande império dividido em dois: a Anatólia, um velho território islamizado, e a Rumélia - os territórios europeus conquistados -, uma fronteira disputada. Entre as duas capitais otomanas, Bursa e Adrianopla, ficava Constantinopla. Caberia a seu filho, Mehmed II Fatih (o Conquistador) eliminar o último vestígio do império romano.

\section{De Constantinopla a Viena}

Quando o século XV começou, havia dois grandes Estados muçulmanos no Oriente Médio: o Egito mameluco e o principado otomano. Ambos tinham relações cordiais e foram igualmente derrotados por Timur ainda na década de 1400. No ocaso do século XV, apenas o agora Império Otomano se recuperara e expandira; as relações entre ambos eram

conflituosas e, na primeira década do novo século XVI, surgiria outro Estado muçulmano no Oriente: a Pérsia safávida. 
A superioridade militar dos otomanos sobre os mamelucos se devia a inovações tecnológicas, especialmente o surgimento de armas de fogo portáteis e o uso extensivo de canhões nos campos de batalha. Os otomanos adotaram imediatamente essas inovações e se mostraram bastante eficazes no seu uso. Já os mamelucos, não podiam adotá-las. Sua cultura guerreira se baseava na furusiyya, o domínio da arte de montar e guerrear a cavalo, e rejeitá-la em proveito das armas de fogo era rejeitar a própria identidade de mameluco, sem contar sua posição política e seu prestígio social. ${ }^{11}$ Em agosto de 1515 e janeiro de 1516, os otomanos impuseram duas severas derrotas aos mamelucos e, após mais um ano de campanha militar, anexaram o sultanato mameluco e a península arábica a seus domínios.

Após essas conquistas orientais, os otomanos voltaram-se novamente para a Europa. Capturando Belgrado em 1521 e Rodes, a base dos cavaleiros hospitalários após sua expulsão do Levante, no ano seguinte, os otomanos, sob a liderança vigorosa do sultão Suleimã I, o Magnífico, solidificaram sua posição nos Bálcãs. O único reino cristão restante no sudeste da Europa era a Hungria e, quando o jovem rei Luís II se recusou a pagar tributo, Suleimã o invadiu em 1526.

Sem esperar por reforços ou se retirar para uma posição fortificada - o que forçaria os otomanos a gastar suas forças em um sítio prolongado -, Luís atacou o exército de Suleimã através do rio Borza com menos de 20.000 homens. Quase toda a nobreza húngara foi eliminada no campo de batalha. Foi o fim do reino da Hungria como Estado independente. Dois terços do território húngaro foram anexados ao Império Otomano e João Zapolya, rei da Transilvânia e vassalo de Suleimã foi coroado rei do restante.

Zapolya, no entanto, foi derrotado por seu rival, Ferdinando da Áustria, e pediu ajuda a Suleimã. Mais uma vez, em maio de 1529, os exércitos muçulmanos marcharam pela Europa, desta vez com o objetivo de tomar a capital do Sacro Império Germânico:

\footnotetext{
${ }^{11} \mathrm{O}$ historiador mameluco Ibn Zabul escreveu a respeito das derrotas mamelucas: "um único de nós pode derrotar seu exército inteiro. Se você não acredita, tente, mas por favor mande seu exército parar de atirar com armas de fogo. [...] você montou um exército de todas as partes do mundo [...] e trouxe consigo essa artimanha astutamente criada pelos cristãos da Europa quando são incapazes de enfrentar os exércitos muçulmanos no campo de batalha. A artimanha é aquele mosquete que, mesmo se uma mulher atirasse com ele, deteria tais e tais números de homens [...] desgraça para ti! Como ousas atirar com armas de fogo contra muçulmanos?"
} 
Viena. O tempo interferiu nos planos de Suleimã. O verão daquele ano foi um dos mais úmidos da década e, no julgamento do historiador Roger Bigelow Merriman, "[as chuvas] foram tão constantes e torrenciais naquele ano que afetaram gravemente o resultado da campanha". Devido às chuvas, Suleimã foi forçado a abandonar sua artilharia pesada, fundamental nas vitórias otomanas desde Constantinopla, e suas tropas demoraram quase cinco meses para chegar até o alvo. Quando chegaram, os vienenses haviam duplicado a guarnição de defesa. Após uma série de ataques infrutíferos, Suleimã decidiu recuar em meados de outubro.

\section{A Turquia e a Pérsia}

Os dois lados, no entanto, viram o fracasso dos muçulmanos em Viena como um adiamento, e não uma derrota. Mesmo a vitória naval de Lepanto, em 1571, tão celebrada na Europa, fez pouca diferença. Quando o sultão Selim II, sucessor de Suleimã, perguntou a seu grão-vizir se seria possível reconstruir a frota após Lepanto, ouviu a seguinte resposta: "o poder e a riqueza do nosso império são tais que se desejássemos equipar toda a frota com âncoras de prata, cordame de seda e velas de cetim, poderíamos fazê-lo". Os otomanos ainda eram o maior poder militar da Europa oriental e nenhuma força européia poderia ser comparada a eles. As palavras do embaixador austríaco em Istambul, Ogier Ghiselin de Busbecq, dão a medida da esperança cristã:

Do lado [turco] há os recursos de um império poderoso, força inalterada, hábito da vitória, resistência ao trabalho árduo, unidade, disciplina, frugalidade e vigilância. Do nosso, há pobreza pública, suntuosidade privada, força debilitada, espírito alquebrado, falta de resistência e treinamento; os soldados são insubordinados, os oficiais avaros; há desdém pela disciplina; licenciosidade, irresponsabilidade, embriaguez e libertinagem são correntes; e o pior de tudo, o inimigo está acostumado à vitória e nós a derrota. Podemos ter dúvida de qual será o resultado? A Pérsia se interpõe a nosso favor; pois o inimigo, enquanto se prepara para o ataque, precisa trazer de olho essa ameaça na sua retaguarda. Mas a Pérsia está apenas retardando nossa sina; não pode nos salvar. Quando tiverem acertado as contas com a Pérsia, os turcos vão voar nas nossas gargantas apoiados pelo poderio de todo o Oriente; o quanto estamos despreparados não ouso dizer!

A Pérsia, única esperança do Ocidente segundo o embaixador, tinha sido reunificada pelo xá Ismail Safávida, no início do século XVI (1501). Soberano político, líder militar e religioso, ele declarou o islamismo xiita como a religião oficial do Estado e, assim, se opôs 
aos otomanos tanto no campo político quanto religioso. Embora derrotada pelo sultão otomano Selim I na década de 1510, a Pérsia safávida permaneceu um Estado separado, rival, e em geral hostil.

Na época, a idéia de uma aliança antiotomana entre a Cristandade e a Pérsia foi levantada por alguns, mas em vão. O xá Ismail enviou uma carta ao imperador Carlos V em 1523, mas a resposta do imperador só chegou ao Irã em 1529, quando o xá já estava morto há cinco anos. Não obstante, os otomanos e os persas continuaram a guerrear entre si até o século XIX, quando ambos os Estados já não eram ameaça para nenhuma potência européia.

\section{Os europeus no Índico}

Os primeiros sintomas de uma possível decadência otomana surgiram no mar. Em 1498, dez anos após Bartolomeu Dias ter dobrado o Cabo da Boa Esperança, Vasco da Gama chegou à Índia inaugurando uma nova rota comercial entre o Ocidente e o Oriente. Já em 1502, a República de Veneza enviou um emissário ao sultão do Cairo para precavê-lo contra o perigo que os navegadores portugueses representavam para sua posição comercial. As expedições navais egípcias contra os portugueses, no entanto, redundaram em fracasso total. Os navios portugueses eram maiores, mais manobráveis em mar aberto e mais bem armados que as galeras egípcias, adaptadas à navegação no ambiente relativamente seguro do Mediterrâneo e do Mar Vermelho.

Após a conquista do Egito em 1516-7, os otomanos tomaram em suas mãos a tarefa de expulsar os portugueses dos mares orientais. No entanto, não dedicaram muitos esforços à tarefa e os resultados foram, na melhor das hipóteses, inconclusivos. Tais embates eram vistos como questões menores, relativas a fronteiras longínquas e desimportantes. Algumas vozes se levantaram alertando para o perigo da superioridade marítima européia no Índico, mas eram poucas e esparsas e suas admoestações receberam pouca atenção.

Um bom exemplo de tal desinteresse foi a expedição otomana a Atjeh, na Sumatra. Em 1563, o governante local, muçulmano, enviou um pedido de ajuda contra os portugueses à Istambul e acrescentando como bônus a oferta de conversão de diversos governantes não-muçulmanos da área, também ameaçados pelos portugueses. Apenas dois 
anos depois os otomanos reuniram uma frota de 19 galeras e as enviaram para auxiliar Atjeh. A maior parte das embarcações, no entanto, foi desviada para o Iêmen e, na verdade, apenas dois barcos chegaram à Sumatra, onde foram facilmente rechaçados pelos portugueses.

O impacto comercial da rota oceânica aberta pelos portugueses foi menor do que se pensou no passado. Durante todo o século XVI, o comércio entre o sul e o sudeste da Ásia, de um lado, e a Europa mediterrânea, de outro, intermediados pelo Oriente Médio, continuou a prosperar. No século XVII, porém, uma situação mais ameaçadora se desenvolveu. Os portugueses - e, junto com eles, holandeses, ingleses e outros europeus -

estavam estabelecendo bases no Índico, que, posteriormente, se tornariam dependências coloniais. Quando estenderam seu controle do mar para os portos, os impérios europeus, a partir de então donos dos pontos de partida e de chegada das mercadorias asiáticas, levaram a melhor sobre os impérios do Oriente Médio.

\section{O front europeu no século XVII}

Durante a primeira metade do século XVII não houve muita movimentação no front ocidental. As principais nações européias estavam envolvidas com a Guerra dos Trinta Anos e os otomanos envolvidos com problemas internos e duas guerras contra a Pérsia (1602-27 e 1630-8). Em 1645, os otomanos entraram em guerra com a República de Veneza e, de início, foram bastante mal. Em 1656, os venezianos tiveram condições de levar uma frota ao estreito de Dardanelos e obter uma vitória naval frente às forças turcas.

Mas, nesse mesmo ano, Mehmed Köprülü foi apontado grão-vizir e, sob sua liderança, a frota foi reconstruída e os venezianos capitularam em 1669, entregando a ilha de Creta aos otomanos. Durante todo o período em que a família Köprülü esteve no poder (1656-78), o Estado otomano se fortaleceu, o que permitiu que seus sucessores no cargo de grão-vizir retomassem a guerra na Europa. Em 1582 Kara Mustafá, primo dos Köprülü, desfechou uma invasão à Áustria e sitiou Viena pela segunda vez em 1683.

As circunstâncias pareciam favoráveis: houve uma revolta nas partes da Hungria controladas pelos Habsburgo em 1681, o exército austríaco contava com menos de 40.000 homens em armas em 1682 e a maior parte desses estava estacionada no Reno para 
enfrentar um possível ataque francês (agentes franceses chegaram a prometer ao Sultão atacar os austríacos caso os otomanos marchassem contra Viena). O exército otomano contava com aproximadamente 100.000 homens e, em 7 de julho, o imperador Leopoldo I fugiu de Viena para Passau, deixando a defesa da cidade nas mãos de seus subordinados.

Por volta de 4 de setembro, o exército otomano conseguiu romper as defesas da cidade e os defensores pareciam não ter alternativa senão a rendição. No entanto, alguns príncipes alemães e, principalmente, o rei da Polônia Jan Sobieski, haviam montado um exército para auxiliar os austríacos. Embora Kara Mustafá soubesse da chegada desse exército, não se preparou para enfrentá-lo e, em 12 de setembro, os otomanos - que, em geral, eram mais fortes no ataque do que na defesa - foram atacados e derrotados por Sobieski. Segundo um cronista da época, "foi uma derrota calamitosa, tão grande como nunca houve igual desde as origens do Estado otomano".

A derrota em Viena abriu o caminho da Hungria e, após três anos de ataques, em 1686 a cidadela de Buda caiu frente aos exércitos coligados de Áustria, Veneza, Polônia, Toscana e Malta. Os turcos lamentaram profundamente a derrota: "Nas fontes eles já não se lavam/ nas mesquitas não rezam mais/ os lugares que prosperavam estão agora devastados./ O austríaco tomou nossa bela Buda”. A série de derrotas otomanas não havia chegado ao fim. A Rússia se associou às potências cristãs e, em 1696, o tsar Pedro I, o Grande, capturou a península de Azov, o primeiro baluarte russo na costa do Mar Negro.

A guerra só chegou ao fím com a assinatura, em janeiro de 1699, do tratado de Carlowitz. Foi a primeira vez em que um Império Otomano derrotado foi obrigado a assinar um tratado de paz. Até então, a negociação de tratados tinha sido fácil: o sultão ditava seus termos e o inimigo derrotado os acatava. Ao negociar em Carlowitz, os otomanos tiveram, pela primeira vez, de usar a diplomacia para tentar minorar suas perdas.

Nessa tarefa, os otomanos tiveram a assistência inesperada da Holanda e da Inglaterra. Esses eram potências primordialmente marítimas e comerciais e não tinham nenhum interesse em ver a expansão da influência austríaca pela Europa central. Em princípio, os otomanos relutaram em aceitar o que lhes parecia ser uma interferência cristã em seus assuntos, mas em breve aprenderam a reconhecer a validade de tal ajuda e a fazer uso dela. 


\section{Os consultores militares europeus}

A utilização de armas européias - e mesmo o uso de financiamentos europeus para a compra dessas - era uma prática antiga no mundo islâmico e tinha suas raízes na época das Cruzadas, muito antes da criação do Estado otomano. O papel dos canhões do engenheiro húngaro Urban no sítio de Constantinopla foi fundamental e os janízaros do sultão foram extremamente bem sucedidos no uso de armas de fogo cristãs, formando uma das melhores unidades militares do mundo durante o século XVI.

A grande novidade para os otomanos foi a utilização de ajuda européia para treinamento militar e a aliança diplomática com potências européias contra outras potências européias. Um documento otomano de princípios do século XVIII mostra uma conversa, provavelmente fictícia, entre um oficial otomano e um cristão. Nessa conversa, os métodos de guerra muçulmano e cristão são comparados e chega-se a sugerir que os muçulmanos deveriam imitar os infiéis na organização militar e na condução da guerra - sugestão completamente impensável antes de Viena e Carlowitz. A ênfase é dada no uso feito pelos cristãos do poder de fogo concentrado e no treinamento realizado para tornar mais eficaz a barragem de mosquetes e canhões. Em síntese, argumentava-se que não bastava adotar armas ocidentais, era preciso também adotar o treinamento e as táticas cristãs para usá-las eficazmente.

Evidentemente, tal modernização não era unânime no pensamento dos otomanos, e as vitórias nas guerras de 1733 e 1743-7 contra os ainda menos ocidentalizados persas enfraqueceu ainda mais a causa dos modernizadores. A segunda metade do século XVIII, no entanto, viu uma série de derrotas otomanas frente aos russos que culminaram com a anexação da Criméia pela Rússia em 1783. O golpe foi sentido em Istambul. A perda de territórios otomanos na Hungria e nos Bálcãs era ruim, mas esses eram incorporações relativamente novas ao território muçulmano. Já a Criméia era um território muçulmano antigo, suas origens remontando à Idade Média e sua perda era como perder parte da Síria ou do Iraque.

Os otomanos, defrontados com a maior crise de sua história buscavam incessantemente uma solução. As perguntas-chave eram: “o que fizemos de errado?”; “o que eles fizeram de certo?"; e, claro, "como podemos alcançá-los?" 
Uma tentativa de respondê-las foi a contratação extensiva de 'especialistas' ocidentais. Se, no início, tais especialistas eram quase sempre aventureiros e renegados, no final do século XVIII era comum que as próprias potências européias tratassem de enviálos como parte de acordos diplomáticos. Um dos primeiros e mais importantes desses enviados foi o barão de Tott, francês de origem húngara que fundou uma escola de matemática na década de 1770 e contribuiu para o treinamento das forças otomanas em engenharia militar e artilharia.

De maneira geral, a maior aliança européia da Turquia otomana foi francesa e a maior parte dos instrutores estrangeiros eram franceses. $\mathrm{O}$ estudo do francês foi tornado obrigatório para todos os alunos das novas escolas militares e navais. A colaboração francootomana não foi interrompida nem ao menos pela Revolução Francesa e tanto o Comitê de Salvação Pública quanto o Diretório auxiliaram as reformas do sultão Selim III. A aliança só chegou definitivamente ao fim quando Napoleão, tentando construir seu bloqueio continental, dividiu as possessões turcas nos Bálcãs entre a França, a Rússia e a Áustria.

\section{A Turquia impotente}

A evidência final da impotência do mundo muçulmano frente às potências européias veio na forma da conquista do Egito por Napoleão em 1798: uma pequena força européia era capaz de invadir com relativa facilidade um dos centros do mundo islâmico. Um pouco mais tarde, os franceses foram expulsos do Egito. Mas o foram por um esquadrão da marinha de outra potência européia, a Inglaterra. Apenas uma potência européia podia derrotar outra potência européia.

A França foi também a fonte direta do principal fator de crise no Império Otomano do século XIX. A chegada ao Mediterrâneo oriental das idéias libertárias da Revolução Francesa acendeu o fogo do nacionalismo nos Bálcãs. A primeira revolta ocorreu na Sérvia, entre 1803 e 1812 e seu exemplo foi seguido em outras regiões, notadamente na Guerra de Independência da Grécia (1821-9), que angariou suporte de filelenos de toda a Europa. Por fim, em seguida a mais uma derrota frente aos russos em 1877, o Império Otomano aceitou, em 1878, no Congresso de Berlim, reconhecer a independência da Sérvia, da Romênia e da Bulgária; com o beneplácito das potências européias, a Áustria ocupou a Bósnia e a Rússia anexou os Bálcãs orientais. 
Era o fim do Império Otomano na Europa. As guerras balcânicas de 1912 e 1913 só fizeram confirmar tal fato, dividindo entre a Romênia, a Grécia e a Bulgária as províncias européias do Império Otomano. Apenas a Trácia oriental permanecia sob controle otomano no início da Grande Guerra de 1914-8. Poucos anos após o final dessa, com mais uma derrota turca, do poderoso Império Otomano não restava nem mesmo o nome. As reformas de Mustafá Kemal Ataturk aboliram o sultanato e laicizaram o Estado, criando, em 1922, a República da Turquia.

\section{Bibliografia}

BLACK, Jeremy. The Cambridge illustrated atlas of warfare: Renaissance to revolution 1492 1792. Cambridge: Cambridge University Press, 1996.

ELIADE, Mircea. A history of religious ideas, vol. 3: from Muhammad to the Age of Reforms. Tradução inglesa, Chicago/ Londres: The University of Chicago Press, 1985 [edição brasileira: História das crenças e das idéias religiosas. Rio de Janeiro: Jorge Zahar, 1978].

HOURANI, Albert. A history of the Arab peoples. Cambridge, Mass.: Harvard University Press, 1991 [edição brasileira: Uma história dos povos árabes. São Paulo: Cia. das Letras, 1994].

KEEGAN, John. Uma história da guerra. Tradução portuguesa, São Paulo: Cia. das Letras, 1995.

LEWIS, Bernard. O oriente médio: do advento do cristianismo aos dias de hoje. Tradução portuguesa, Rio de Janeiro: Jorge Zahar, 1996.

. O que deu errado no Oriente Médio? Tradução portuguesa, Rio de Janeiro: Jorge

Zahar, 2002.

. Os assassinos: os primórdios do terrorismo no Islã. Tradução portuguesa, Rio de Janeiro: Jorge Zahar, 2003.

RABB, Theodore K. Se o verão não tivesse sido tão úmido. In: COWLEY, Robert (ed.). E se...? Rio de Janeiro: Campus, 2003, pp. 139-152.

RUNCIMAN, Steven. A queda de Constantinopla 1453. Tradução portuguesa, Rio de Janeiro: Imago, 2002. 